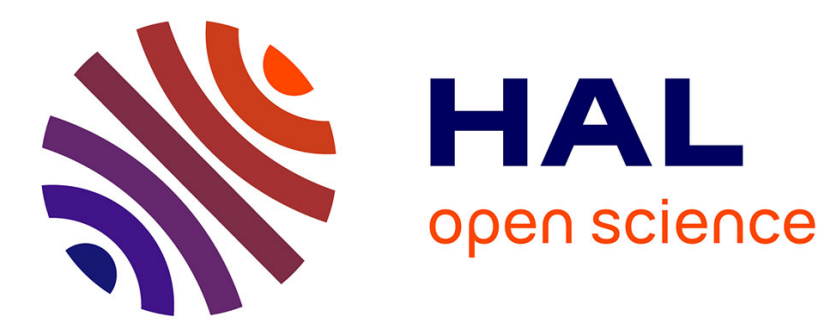

\title{
Social Innovation and Service Innovation
}

Faridah Djellal, Faïz Gallouj

\section{To cite this version:}

Faridah Djellal, Faïz Gallouj. Social Innovation and Service Innovation. Conference "Challenge Social Innovation", Sep 2011, Vienne, Austria. 10.1007/978-3-642-32879-4_8 . halshs-01113990

\section{HAL Id: halshs-01113990 \\ https://shs.hal.science/halshs-01113990}

Submitted on 6 Feb 2015

HAL is a multi-disciplinary open access archive for the deposit and dissemination of scientific research documents, whether they are published or not. The documents may come from teaching and research institutions in France or abroad, or from public or private research centers.
L'archive ouverte pluridisciplinaire HAL, est destinée au dépôt et à la diffusion de documents scientifiques de niveau recherche, publiés ou non, émanant des établissements d'enseignement et de recherche français ou étrangers, des laboratoires publics ou privés. 


\title{
Conference "Challenge Social Innovation", Vienna (Austria), 19-21 September 2011
}

\author{
Social innovation and service innovation
}

\author{
Faridah Djellal and Faïz Gallouj \\ Clersé, Université Lille 1
}

\begin{abstract}
Summary:
Social innovation and service innovation issues have developed separately over the last two decades, with too rare intersections between them. Both issues share many points in common, however, and sometimes even describe the same socio-economic reality. This paper aims to help establish dialogue between these two still marginal but promising fields of economic theory and the social sciences in general. It briefly describes each of these two fields, puts them into perspective, and examines the links between them in a number of different ways.
\end{abstract}

\section{Introduction}

The issues of social innovation, on the one hand, and service innovation, on the other, still play a very marginal role in economic theory. The main reason for this neglect is probably the relationship to the market (or lack thereof, real or imagined) in the first case, and the relationship to materiality in the second case. In fact, social innovation is often considered as a response to market (and also state) failures and services are primarily defined by their lack of materiality.

However, although these issues are not central to economic theory, they have been the subject of a growing body of literature over the last two decades, and this trend shows no signs of slowing. This success can be explained in particular by the chronic socio-economic crisis experienced by developed economies since the 1970s, demographic change (ageing populations in rich countries, in particular), the failure of development policies, the rise of environmental concerns, and the return to favour of the service society in economic thought and institutional and political debate. What we are witnessing is the challenging of the myths of unproductive services, of low capital intensity, low levels of innovation, poorly suited to exchange, and the myth of the service society as a "society of servants" (Gallouj, 2002a).

As we highlight in this paper, these two issues have many points in common. Firstly, social innovation is very often a service innovation (a new intangible solution), whether it emerges in a service sector organisation (innovation in services), the industrial or agricultural sectors (service innovation), civil society, social movements or heterogeneous collective entities in which stakeholders from these different fields are involved. However, more generally, beyond this potential identity, efforts to define social innovation and service innovation come up against the same obstacles: a degree of invisibility (to traditional indicators for measuring innovation, such as R\&D and the registering of patents), the key role played by informal processes and interaction (coproduction), appropriation regime issues, and the failure or inadequacy of public support policies.

Despite these commonalities and this identity (in certain cases), these two research trajectories have rarely intersected, with few exceptions (Gershuny, 1978, 1983; Crozier et al., 1982; Harrisson et al., 2010, for example). This does not mean, of course, that the economics and socio-economics of services never address the issue of social innovation or that social 
innovation specialists never touch on the subject of services. It does mean, however, that the substantive dialogue, to the extent that it can be given a tangible form, for example through the exchange of references (mutual citations) between these two scientific communities, is particularly limited. Therefore, in their efforts to define social innovation, social innovation specialists often take the established and solid field of technological innovation as their benchmark and ignore the debates, though close to their own, but less well-established, in the field of innovation in services.

There are several explanations for this strange mutual ignorance. The first explanation, as far as services are concerned, would appear to be the initial focus in the literature on technologist approaches, based on the principle of assimilation, which assumes that innovation in industry and innovation in services have a similar identity, whereas social innovation tends more immediately towards the intangible, non-technological aspects of innovation. A second explanation may be the initial focus of these studies on knowledge intensive business services (KIBS) to the detriment of "proximity" personal services, or public services, which are more sensitive to social innovation. Another explanation is the disciplinary division of labour apparent in these studies. In fact, social innovation is more likely to be a subject addressed by sociologists, whereas the service innovation or innovation in services fields are (mainly) dominated by economics and management sciences.

In the field of innovation in services, the weakening of the "assimilationist" or technologist approach and the rise of "service-based" (demarcative) and "integrative" approaches, alongside the shift from empirical studies of knowledge intensive business services (KIBS) towards less complex services (personal services, local services, "care" services and public services), and the rise of multi-disciplinary approaches, provide a strong argument for a closer relationship between the two issues.

The very aim of this article is to help establish this dialogue between these two issues. The first two sections are devoted to a brief account of the two notions of social innovation and service innovation, from the point of view of their nature, and the way in which they have emerged and are organised. For each notion, they highlight the different analytical perspectives that make them scalable in scope. The third section puts the established results into perspective and examines, in different ways, the links between social innovation and services and service innovation.

\section{Social innovation: the desperate quest for a definition}

Social innovation remains a particularly fuzzy notion, despite numerous efforts to clarify its meaning. It is heterogeneous, eclectic and flexible in scope (Cloutier, 2003; Goldenberg, 2004; Moulaert et al., 2005; Danduran, 2005; Harrisson and Klein, 2007; Drewe et al., 2008; Harrisson et al., 2010; Harrisson and Vezina, 2006; Pol and Ville, 2009; Howaldt and Schwarz, 2010; Phills et al., 2008, Hamalainen and Heiskala, 2007).

Both the noun "innovation" and the qualifier "social" in the expression "social innovation" are problematic.

The term "innovation" raises the traditional question (and this applies to all forms of innovation) of where to draw the line between change and actual innovation. This question is especially relevant to social innovation. A relatively more flexible and looser definition of newness seems to be used in the socio-economics of social innovation, compared with the traditional innovation economics. According to the reference study on this subject by Chambon, David and Devevey (1982, p. 11 and 13), "the term social innovation covers 
practices that are not necessarily new, if by new we mean original or inventive. In contrast with technological innovations, social innovations are rarely original or inventive (...) The practices in question contrast with existing practices. (...) New means "not fixed", "not restrained", and in particular "out of the ordinary" (...) to innovate is not to do something new, but to do it in another way, to propose an alternative. And this alternative can sometimes be re-rooted in previous practices."

The qualifier "social" raises even tougher problems to the extent that it can be interpreted in many different ways. It can, in principle, be used to describe any human activity, a particular sector, a particular type of problem, a particular way (method) of approaching a problem (involvement and empowerment), a particular motivation or intention on the part of the innovator, a particular impact of the innovation, the non-economic aspect of economic interventions, etc. (Harrisson et al., 2010, Phills et al., 2008). The literature on this subject offers us varying and more or less satisfactory perspectives from which to address the issue of social innovation. These perspectives cover a more or less broad scope. An extreme perspective consists of understanding the qualifier "social" in its broadest sense (the relationship with society). Since innovation is an activity performed to solve problems (which are social by definition), all innovations are social. The expression "social innovation" would therefore appear to be a pleonasm. Innovation as traditionally interpreted by economists (technological and organisational innovation) is a component of social innovation, just like other types of innovation (artistic, cultural, legal, etc.). Of course, the more general and universal the concept of social innovation, the lower its scientific value, since if everything becomes social innovation, nothing can any longer be social innovation. We therefore need to define the limits of social innovation if we want this concept to have a certain usefulness and relevance. The most common solution consists of defining social innovation with reference and in opposition to business innovation. We will now go on to explore this solution in greater depth before providing a more detailed account of certain general characteristics of social innovation found in the literature on this subject.

\subsection{Social innovation in opposition to business innovation}

In their search for an operational definition for and a theory of social innovation, the specialists concerned have naturally turned towards the well-established field of innovation economics, particularly the founding works of Schumpeter and the Neo-Schumpeterian school. Social innovation is therefore considered in opposition to what, for the sake of convenience, we might call business innovation (although economists rarely use this term) to essentially describe technological innovation, but also organisational innovation. Business innovation exists outside and is complementary to social innovation. It is, first and foremost, an industrial innovation, to the extent that corresponding theoretical constructions, starting with that of Schumpeter, were developed for the industrial sector.

This general perspective is aptly illustrated by the typology in table 1 (adapted from Hochgerner, 2009). Business innovation includes the categories found in the Oslo Manual (OECD), which in turn draw on Schumpeter's well-known typology ${ }^{1}$. It covers, as a result, technological product and process innovation and non-technological organisational and marketing innovation. Social innovation, on the other hand, relates to civil society, social movements, the state, but also business. Hochgerner subdivides social innovation into three

\footnotetext{
${ }^{1}$ This typology distinguishes between five types of innovation: the introduction of a new product and a new process, the opening of a new market, the discovery of a new source of raw materials and other inputs, and the creation of a new organisation.
} 
sub-categories which are indicative examples: stakeholder involvement, procedures in decision making and behaviours.

Table 1: Typology of innovation (after Hochgerner, 2009)

\begin{tabular}{|c|c|c|c|c|c|c|}
\hline \multicolumn{2}{|c|}{$\begin{array}{c}\text { Technological innovations in } \\
\text { economic production }\end{array}$} & \multicolumn{2}{|c|}{$\begin{array}{l}\text { Non-technological innovation } \\
\text { on company levels }\end{array}$} & \multicolumn{3}{|c|}{$\begin{array}{l}\text { Social innovations in business, civil society, } \\
\text { state }\end{array}$} \\
\hline Product* & Process* & Organisation* & Marketing* & Participation & Procedures & Behaviours \\
\hline
\end{tabular}

* Innovation as defined by the Oslo Manual (OECD, 2005)

This typology raises a number of comments.

1) While it includes technological product and process innovations and several forms of nontechnological innovations (organisation, marketing, participation, procedures and behaviours), it omits non-technological product innovation (service innovation). Although excluded from the Oslo Manual for the moment, it is a frequent form of innovation in the services sector. Examples of such forms of innovation include new financial products, new insurance contracts, new fields of consultancy expertise, etc. Non-technological product innovation is also increasingly common in industrial firms supplying numerous new "industrial" services (Furrer, 2010) such as pre-sales services, after-sales services and services unrelated to sales. It is important to include this type of non-technological product innovation within both business innovations and social innovations (cf. table 2).

2) To better account for social innovation in businesses, we suggest separating it from other fields of social innovation (those implemented by civil society and the state), by introducing a separate type of innovation (table 2). Social innovation in business may therefore include participation, procedures and behaviour, as well as a product, process, service, organisation and marketing.

According to Hillier, Moulaert and Nusbaumer (2004), "orthodox social science studies in the 1990 s used the term 'social innovation' primarily in reference to the transformation of organisations to optimise their efficiency". In other words, social innovations are organisational innovations, such as total quality, re-engineering, just-in-time production and self-service. Cloutier (2003) confirms the finding that social innovation in business refers essentially to new forms of work organisation. According to her is possible, however, to distinguish between two different perspectives in social innovation studies. In the first perspective, social innovation is "a new social arrangement that promotes knowledge creation and technical innovation" without any particular reference to quality of life at work. The second perspective describes new forms of work organisation as social innovations because their primary purpose is to improve quality of life at work.

These discussions highlight a number of problems that arise when we try to draw a line between different types of innovation, starting with the difference between "pure" ("nonsocial") organisational innovations and social organisational innovations. It is probable that a fair share of social innovation in business does not (or no longer) go undetected in our identification and measurement systems, since it can be assimilated with organisational innovation. It is also difficult to draw a line between different types of social innovations, that is, between social innovations relating to participation, procedures and behaviours, on the one hand, and organisational or process innovations, on the other hand. These two groups appear, in certain cases, to be identical and redundant.

3) Social innovation in civil society, social movements and the state is likely to involve not only procedures, participation and behaviours, as suggested by Hochgerner's typology, but 
also organisations, processes (unless these two categories are identical to the previous three) and "products", as well as services.

Table 2: A new typology of innovation

\begin{tabular}{|c|c|c|c|c|c|c|c|c|c|c|}
\hline \multicolumn{4}{|c|}{ Business innovation } & \multicolumn{7}{|c|}{ Social innovation } \\
\hline \multicolumn{7}{|c|}{ Innovation in firms } & \multirow{2}{*}{\multicolumn{4}{|c|}{$\begin{array}{c}\text { Innovation in civil society, stat } \\
\text { Social innovations in civil society, state }\end{array}$}} \\
\hline \multicolumn{2}{|c|}{$\begin{array}{l}\text { Technological } \\
\text { innovations in } \\
\text { economic } \\
\text { production }\end{array}$} & \multicolumn{2}{|c|}{$\begin{array}{c}\text { Non-technological } \\
\text { innovation on company } \\
\text { levels }\end{array}$} & \multicolumn{3}{|c|}{ Social innovations in business } & & & & \\
\hline Product & Process & Organisation & Marketing & $\begin{array}{l}\text { Participation } \\
\text { nartion }\end{array}$ & Procedures & Behaviours & Participation & Procedures & Behaviours & \\
\hline & & $\begin{array}{l}\text { Nt product } \\
\text { (Service) }\end{array}$ & $\begin{array}{c}\mathrm{Nt} \\
\text { process }\end{array}$ & Product & Process & $\begin{array}{c}\text { Organisatio } \\
n\end{array}$ & Product & Process & $\begin{array}{l}\text { Organisati } \\
\text { on }\end{array}$ & $\begin{array}{l}\text { Nt product } \\
\text { (service) }\end{array}$ \\
\hline & & & & Marketing & $\begin{array}{l}\text { Nt product } \\
\text { (Service) }\end{array}$ & & & & & \\
\hline
\end{tabular}

4) This typology should not lead to a static interpretation of, or blind us to, the dynamic relationships between different types of innovation. It is important to note that, as stated by numerous economists (Schumpeter, 1942; Kuznets, 1974; Freeman, 1991), "business" innovations are not independent of social innovations. Technological innovation needs to rely on social innovations to develop effectively. The success of the automobile as a technical artefact is closely linked to social or service innovations, such as garages, petrol stations, driving schools, road signs, insurance and rescue services, car loans, and traffic management systems. Conversely, social innovation can give rise to technological innovations. This essential link between technological innovation and social and institutional innovation lies at the heart of the sociotechnical paradigm concept (Perez, 1983; Djellal, 1995) and all theoretical constructions relative to systems and networks (Lundvall, 1992; Callon, 1991; Edquist, 1997).

5) Neither should this typology restrict innovation, either technological or social, to institutional limits (an organisation or business, civil society, or the state). On the contrary, like technological innovation, and probably to a greater extent, social innovation can develop in heterogeneous networks of variable sizes and involving multiple agents. The open nature of social innovation does not, it should be stressed, make the process of identification and measurement any easier.

\subsection{General characteristics of social innovation}

Various attempts to define social innovation have highlighted a number of characteristics which help reveal the (fluctuating) outline of this innovation without providing us with a satisfactory definition. Social innovation is therefore often defined in the following terms, which describe its form or nature, its process and stakeholders, its target, and its purposes: it is supposed to be intangible, non-technological, organisational, non-market, informal, local, designed to solve social problems, etc. However valuable in helping us define social innovation, these different characteristics do not provide us with indisputable technical criteria. Because it is easy to identify exceptions that call them into question, these characteristics need to be put into context and simply be considered as a series of clues.

\section{The target of social innovation}

As Cloutier notes (2003) in her excellent review of the literature on the subject, social innovation can aim at three interlinked targets: the individuals whose well-being it seeks to ensure, the environment or territory (considered at a local, regional, national and supranational level) of which it needs to ensure the economic development and moderate any adverse effects (urban growth, pollution, inequality, etc.), and finally the firm or organisation, 
of which it seeks to increase the performance. In the latter case, social innovation refers mainly to new forms of work organisation and changing power structures.

\section{Form and nature}

Socio-economic studies often refer to social innovation as an intangible or immaterial entity (a new service, organisation, procedure, behaviour, institution, law, etc.). As Cloutier (2003) stresses, "[social innovation] refers mainly to 'ways of doing', actions and practices. It is the opposite of the idea of product." This intangibility assumes that social innovation is the opposite of technological innovation and very closely related to organisational innovation.

However, the relationship between social innovation and intangibility is debatable. Without going so far as to consider all technological innovation as a social innovation since it resolves a social problem, there are many examples of technological (and therefore material) innovations with a social purpose (even in the limited sense of inclusion or social cohesion). These could include, for example, clean technologies, generic drugs and telephone help lines. These examples also challenge the strictly organisational nature of social innovation. However, to maintain the assumption of intangibility, it is possible to consider that social innovation does not reside in the technical artefact as such, but in the additional service characteristics (functions) it introduces and which are social and civic by nature. This is the logic adopted in characteristics-based approaches to innovation in services, which are explored below (Gallouj and Weinstein, 1997; Windrum and Garcia-Goni, 2008).

\section{Process and stakeholders}

Social innovation differs from traditional innovation not simply in its "nature" but also in its modes of production and its stakeholders. Another key characteristic of social innovation is its local or grass-root nature and the essential participation of users in its emergence and implementation. User participation includes the notion of co-production, which is central to service economics and management. However, its scope may be even wider, since it may also mean the capacity of the user to take charge of or take back control over their life, environment (and territory) and future. Some authors go so far as to define social innovation mainly or even exclusively in relation to this active participation element alone (Lallemand, 2001). The production processes in question are often local or grass-root processes in which informality and a variety of stakeholders play a major role.

It is not difficult to imagine how a social innovation that is technological in nature (a technological artefact) could be developed in laboratory conditions without the participation of the user. In the same way, we can find exceptions to the "informal" and "local" ("grassroot") dimensions of social innovation. It is true that social innovation in the social economy is often generated by social stakeholders from civil society, acting either independently or with the support of the state, or by forming partnerships, whether within community groups, social movements or social entrepreneurship (Harrisson et al., 2010). However, within a historical perspective, it is also possible to list the major changes in the social economy and national political governance within a formalized top-down perspective.

\section{Purposes}

The purpose of social innovation is not (directly) economic. Promoters of this form of innovation are generally not motivated by the prospect of maximising their profits. Generally, their activity is not-for-profit or generates little profit. The purpose of social innovation is to resolve social problems. However, the term "problem" should not necessarily be given a negative meaning (in this case, social difficulties). As Milan Kubr (1988) suggests in another context (consulting), it is possible to distinguish between corrective, progressive and creative 
problems. In the traditional case of corrective problems, innovation is a therapy used to rectify a difficult situation. Progressive problems involve improving a given situation which we fear, in advance, is going to worsen. Creative problems, meanwhile, involve creating a totally new situation. Social problems which are resolved by social innovation are not just any social problems. They are problems that cannot be resolved by "traditional" innovation due to market or state failures or disinterest. More generally, in the search for solutions to different types of problems, the purpose of social innovation is to increase the quality and quantity of life of an individual or group of individuals (Pol and Ville, 2009) or enhance their "betterbeing" (Bouchard et al., 1999). This quality of life or "better-being" purpose occurs at the different levels (targets) mentioned previously - the individual, the territory and the business.

Although it is true that social innovations primarily aim to achieve social development (which can be expressed in a simplistic way as the idea of quality of life), the purpose of certain social innovations is (also) business development. This covers, for example, inclusion schemes for people in difficult social situations, microfinance (the granting of microloans and saving or insurance schemes for poor people excluded from the traditional banking system). Many social innovations within firms combine both social development and economic development purposes. These are organisational innovations fostered by management or delivered lower down the hierarchy that improve the quality of work of employees and have a positive impact on firms productivity. Certain social innovations developed to satisfy a social development need may also be adopted by firms seeking to maximise their profits. Teleeducation and telemedicine are just two examples.

\section{Service innovation: making "invisible innovation" visible}

Although much remains to be done across a range of fields to do justice to and make the most of the business activities driving today's economies to a large extent, the literature on innovation in services has undeniably taken off in recent years (Gallouj and Weinstein, 1997; Sundbo, 1998; Miles, 2002; Den Hertog, 2002; Gallouj, 2002b; Rubalcaba, 2006; Windrum and Garcia-Goni, 2008; Tether, 2005; Hipp and Grupp, 2005). A number of literature reviews have been produced recently (Gallouj and Savona, 2009; Howells, 2007; Gallouj and Djellal, 2010; Gallouj, 2010). Rather than going into detail about the content of these different works, we will provide an overview of certain results, which are important in our eyes, as a basis for debate with the social innovation field.

\subsection{The specific nature of services and their impact on innovation}

Extending Adam Smith's observation that "services perish in the very instant of their production...", economic studies in this field have sought to define the intrinsic characteristics of these activities. Services are therefore considered as immaterial or intangible and interactive (co-produced). These theoretical characteristics are ideal types which provide the basis for the development of a number of hypotheses on the specific nature of innovation in services.

The intangibility of a service refers to the fact that its product is an act, a treatment protocol or a formula - in other words, a process and an organisation. In many cases, it is difficult to map the boundaries of the service. The "topography" of services should not only take into account their degree of materiality or tangibility, but also the service's timeframe (the service "in acts" as opposed to its long-term effects). In other words, unlike a good, a service does not have an independent existence enshrined in its technical specifications. It is a social construction that exists in various ways in time (time horizon) and in the tangible world (degree of tangibility). 
The fuzziness (immateriality and intangibility) of output has a number of implications for innovation analyses. It can deflect analyses towards the most tangible components of the service, particularly processes (whether they are innovative or not). It makes it difficult to distinguish between product innovation (generally understood as the development of new functionalities and qualities) and process innovation (to reduce costs), to estimate the degree of newness (and the difference between a real innovation and traditional differentiation and diversification mechanisms), and to enumerate the innovation or assess its economic impact (in terms of jobs or impact on sales, for example). The intangible and volatile nature of the "product" compromises efforts to protect the innovation and facilitates its imitation. On the other hand, intangibility makes it possible to envisage the existence of intangible product and process innovations, as well as forms of innovation that aim to make the service less fuzzy (formalization innovation).

Interactivity, the second characteristic of services, refers to a certain form of customer participation in the production of the service (coproduction). It has different theoretical consequences for innovation, both in terms of its nature and the way in which it is organised. It reveals the importance of certain specific forms of innovation - custom-made innovation and ad hoc innovation - which escape both theoretical apparatus and traditional measurement tools. It does not appear to be compatible with the traditional linear conception of innovation which assumes the existence of specialist R\&D structures independent of production and marketing structures. On the other hand it is particularly consistent with the interactive innovation model (Kline and Rosenberg, 1986), which focuses in particular on project groups of varying sizes, involving different company professionals as well as customers. Therefore, the customer is not only the co-producer, he may also be the co-innovator, which raises innovation appropriation problems.

\subsection{Taking into account "invisible" innovation}

As far as the overall concept of innovation in services is concerned, there has been a shift in perspective (according to the framework developed by Gallouj, 1994) from assimilation to demarcation followed by integration. The initial reduction of innovation in services to production and, more generally, to the simple adoption of technical systems, was followed by attempts to identify specific forms of innovation invisible to traditional apparatus; innovation in services and in goods were then considered in terms of integration, in a context of convergence between goods and services. Integration assumes that innovation in goods and in services, technological innovation (visible innovation) and non-technological innovation (invisible innovation) must be analysed using the same tools.

Visible innovation is innovation measured by traditional indicators, such as R\&D and patents. It reflects a technological and assimilationist vision of innovation in which innovation is, in the main, rooted in the production of science-based technical systems. Limiting innovation to such a conception leads to a result in which services are relatively less innovative than industry, despite the advances associated with the inclusion of ICTs. This technological and scientific conception of innovation only reveals the tip of the innovation iceberg.

Invisible or hidden innovation represents a major and still largely neglected field of research that requires further exploration. Invisible innovation is not a homogeneous category. Its diverse expressions are often grouped under the heading of non-technological innovation. This convenient expression hides the sheer diversity of innovation forms, including social innovations, organisational innovations, methodological innovations, marketing innovations, and intangible product and process innovation. 
The non-technological character of these invisible innovations does not mean that they do not or cannot rely on a tangible technology (information or telecommunication systems or modes of transport, for example), but rather that they are not consubstantial with them and in certain cases they can exist without them. In other words, it would be unwarranted to consider that innovation only exists when the novelty is embodied in a technical system. To think otherwise would be to seriously underestimate the capacity for innovation in services.

Certain non-technological forms of innovation (in services but also in manufacturing industry) are taken into consideration in OECD manuals and international surveys (e.g. CIS), although this is a very recent development. The Oslo Manual devoted to innovation indicators, has been revised several times. As well as technological product and process innovations, the latest version of the manual (2005), which has relatively limited empirical applications, also distinguishes between marketing innovations and organisational innovations. Successive community innovation surveys (CIS) have therefore taken into account an increasingly large number of services and certain "non-technological" forms of innovation. The innovation gap has narrowed, although there is still room for improvement, particularly in the following fields: non-technological product innovations (a new insurance contract, a new financial product, or a new field of consultancy expertise, for example), nontechnological process innovations (methodologies and protocols), ad hoc and custom-made innovations, innovation in public services, innovation in complex packages, also called new concepts, and new formulas (for example in commerce, the hotel industry, etc.).

\subsection{Sectoral shift in empirical surveys}

The earliest studies devoted to the specific nature of innovation in services focused on a particular category of services (considered as the most representative of the specific characteristics of these activities), that is, knowledge intensive business services, particularly consulting (Gadrey and Gallouj, 1998; Miles et al. 1994). The hypothesis underlying this choice is the idea that if innovation in services has specific characteristics, it is easiest to find empirical examples in the purest services (that is, the most intangible and interactive).

Research in the field of pure services and knowledge intensive services (KIBS, banks and insurance) was followed by studies relating to the specific characteristics of innovation in services, often considered as less noble or less knowledge intensive (transport, cleaning and care services for the elderly). There has also been a recent renewal of interest in innovation in public services (Windrum and Koch, 2007; Becheikh et al., 2009).

It would be tedious and pointless to describe the many ad hoc types of innovation developed in these different activities. The important point to bear in mind is that forms of nontechnological innovation have been identified everywhere, and they are generally not detected by traditional tools.

This sectoral shift of empirical studies on innovation towards "proximity" services and public services is likely to foster links between the fields of social innovation and service innovation.

\subsection{From a linear model to an open model}

The dynamics of innovation can either be spontaneous (unpredictable) or planned (predictable). Innovation is planned and predictable when it takes place within clearlyidentified structures (for example, R\&D departments and project groups) and in accordance with pre-established processes. Planned innovation activities of this type are, of course, implemented by service organisations (Sundbo and Gallouj, 1999; Tidd and Hull, 2010). 
There is a strong theoretical tradition within the management sciences that recommends applying New Product Development (NPD) methodologies to services, that is, considering the creation of new services as part of planned and systematic processes within the framework of a theoretical perspective termed New Service Development (NSD) (Scheuing and Johnson, 1989; De Brentani, 1991).

However, the literature on innovation in services has focused on the role of interactive structures and processes, forming part of a general open innovation perspective and covering a range of more or less sophisticated and formalised cooperative models.

The general open innovation perspective includes Kline and Rosenberg's chain-linked interaction model or interactive model mentioned earlier. However, it also covers a certain number of unplanned or emergent models such as the rapid application model, the practicebased model, bricolage innovation and ad hoc innovation. The rapid application model is a model in which planning does not precede production, as in the traditional linear model. Once the idea has emerged, it is immediately developed as the service in question is being provided. As such, the service provision process and the innovation process are one and the same (Toivonen, 2010). The practice-based model consists of identifying changes in service practices, developing them and institutionalising them. The bricolage innovation model describes change and innovation as the consequence of unplanned activities performed in response to random events, characterised by trial and error and "learning on the job" (Sanger and Levin, 1992; Fuglsang, 2010; Styhre, 2009). Ad hoc innovation (Gallouj, 1991; Gallouj and Weinstein, 1997) can be defined as the (original) solution development process for a corporate customer problem. This interactive process, which requires the participation of the customer, is described as ad hoc because it is "unplanned" or "emergent", which means that it is consubstantial with the service provision process from which it can be separated only in retrospect. Ad hoc innovation is only recognised as such after the event.

Open innovation also covers specific innovation networks - Public-private innovation networks in services (servPPINs) - that are still relatively unknown ${ }^{2}$ but which develop in a dominant service economy. These servPPINs describe the collaboration (cooperation) between public, private and third-sector service organisations in the field of innovation (Gallouj, Rubalcaba, Windrum, 2012). They differ from traditional innovation networks in several ways. Firstly, the relationships between public and non-profit stakeholders and private stakeholders are placed at the centre of the analysis. Next, service providers are the key stakeholders in the process. Lastly (and the corollary of the previous characteristic), nontechnological innovation (service innovation), often neglected in the literature, is also taken into account. The development of servPPINs in our economies can be interpreted as a statistical phenomenon and a social construction. In fact, although there is an actual increase in the number of servPPINs, this increase is also due to a simple awareness of their existence, that is, the discovery of a reality invisible up until now. The recognition of this type of innovation network is closely linked to the recognition of forms of service innovation hidden from or invisible to our traditional indicators.

Open innovation also covers the user/customer/demand-driven innovation dynamic, which is particularly important in services.

\footnotetext{
${ }^{2}$ These innovation networks were the subject of a European project called ServPPIN (The Contribution of Public and Private Services to European Growth and Welfare, and the Role of Public-Private Innovation Networks, FP7).
} 


\section{First elements of a dialogue between social innovation studies and service innovation studies}

This third section puts social innovation, on the one hand, and services and service innovation, on the other, into perspective in order to outline potential areas for debate between the two fields. We will start with a brief overview of what services studies tell us about social innovation and what social innovation studies tell us about service innovation.

\subsection{What services studies tell us about social innovation and what social innovation studies tell us about services}

As we pointed out in the introduction, social innovation and service innovation issues have, in the main, developed separately with very little interaction between them. In theoretical terms, mutual references between the two fields are therefore rare. Below are some exceptions to the rule.

\section{Gershuny's vision of social innovation: a restrictive, technological and economic conception}

Among the service economics specialists, the author who has taken a close interest in the field of social innovation is Gershuny (1983), the promoter of the self-service theory (see also Gershuny and Miles, 1983). According to Gershuny, the advent of the self-service society (or the relative decline of services) can be explained by social innovation, defined as a change in the way a need (function) is satisfied by the consumer. Consumer needs can, in fact, be satisfied in two different ways, either by calling on the formal sector (acquiring services from an external service provider) or the informal sector (the combination of two factors: a purchased good (equipment) and the work necessary to implement it). There are many examples of this choice, of which the most obvious ones are the transport function, which can be satisfied through the use of private vehicles, or the use of public transport or taxis; and the leisure function, which can be satisfied by going to the theatre, cinema or a concert, or by buying audio-visual equipment (radio, television, DVD player, etc.). Social innovation is the transition from formal to informal satisfaction. It consists of a dual technological and social component. The implementation of this conceptual apparatus at the analytical and statistical levels leads Gershuny to conclude that social innovation has given rise to a shift from a service society to a self-service society (that is, a preference for the "informal" satisfaction of a need). The main analytical argument used to explain these developments is the relatively low productivity of services and therefore their relatively higher price compared with goods.

For Gershuny, social innovation has a major economic and technological component that differs from the conventional (and often broad and vague) definitions outlined above. According to Gershuny's own terms $(1983$, p. 50) "social innovation' is used to describe the process whereby the modal split changes over time. (This is a special usage excluding some categories of social change that would be included in a broader application of the term)".

\section{Beyond technological conceptions of social innovation}

The social content of social innovation (that is, the intervention of lifestyles and their changes) makes it possible to consider an element neglected up to now in purely technological approaches: the participation of the users and their intervention as consumers who have to choose between different solutions. However, Gershuny's contribution from this viewpoint remains limited because he considers social innovation as only consubstantial with material 
technology. However, as stated in Dumoulin et al. (1991), "this innovation will sometimes have a technological component but will always ${ }^{3}$ have a social component".

Normann (1984, p. 84) gives a much broader meaning to this social content. According to him, one of the reasons why service innovation is less spectacular than industrial innovation is that it is founded on social innovations, that is, "innovations that create new types of social behaviour, use social or human energy more efficiently, and link social contexts in a new way".

As such, social innovation is not limited to the way in which the customer participates or makes a choice, but also includes:

- Using technical or human production capacities which are unused and which are there to be used. Some IT service firms have therefore been set up to use the overcapacity of the IT departments of large firms (Crozier et al. 1982). In the same way, some firms specialising in language holidays have built their success on using the following overcapacities: empty schools during holiday periods; mid-week charter flights; English teachers looking for extra income, but above all to perfect their own knowledge of the language; families who want to host foreign students for financial reasons or to improve their social image.

- The introduction, in an organisation, of new functions leading to new roles or sets of roles. An established and well-known example of this type of social innovation is Club Med's "nice organisers" (or G.O.s).

- Linking up contexts and stakeholders with potentially complementary needs. J.C. Decaux is an example of this type of social innovation. The service provided by this company is based on linking up four groups of stakeholders: local authorities to whom bus shelters are provided free of charge and which they are not responsible for maintaining; the advertisers who rent quality, well-maintained advertising media (bus shelters); passengers of buses and the general public who benefit from the advantages offered by this "urban furniture".

Integrating social innovation into representations of services and innovation in services: characteristics-based approaches

The characteristics-based approach to services is a theoretical construction (inspired by the work of K. J. Lancaster), which claims to provide an integrated theoretical representation of innovation in goods and services. Gallouj and Weinstein (1997) (see also Gallouj, 2002a) define the product (whether a good or a service) as the interlinking of vectors of characteristics and competences: service characteristics [Y], internal [T] and external [T'] technical characteristics, internal $[\mathrm{C}]$ and external [C'] competences. Innovation then emerges through the dynamics of these characteristic, which can be added, subtracted, associated, dissociated, etc.

Gallouj (2002b, see also Djellal and Gallouj, 2010) considers that such a representation is able to take into account certain "social" aspects and certain dimensions of social innovation. It can include sustainable service characteristics, on both a socio-economic and an environmental level (for example, socio-civic service characteristics), and any corresponding technical competences and characteristics. The following socio-civic characteristics of postal services serve as a good example (see Gallouj, Gadrey, Ghillebaert, 1999): fair treatment for users (counters, delivery rounds), fairness in accessibility, non-discrimination (young people, foreigners) in customer contact, assistance for marginalised populations, social prices and social banking services (accounts for low-income earners, reasonable penalties, advice for individuals living in hardship).

\footnotetext{
${ }^{3}$ Our italics.
} 


\section{What social innovation studies tell us about service innovation}

The bridges established by the social innovation school with the innovation in services school seem to be more fragile. Social innovation is much more concerned with forging links with the theory of (industrial) innovation and constructing an identity in relation to it. None of the theoretical references mobilised in this paper are really based on core studies on innovation in services, with the exception of a chapter by Harrisson et al. (2010) in the Handbook of innovation and services (Gallouj and Djellal, 2010).

- Although from a theoretical point of view social innovation tells us nothing or not so much about service innovation, that does not prevent services from often being mentioned in definitions of social innovation. Below are several significant examples (our italics).

[Social innovations are] "Innovative activities and services that are motivated by the goal of meeting a social need and that are predominantly developed and diffused through organisations whose primary purposes are social” (Mulgan et al., 2007, p. 8).

"Social innovators identify and deliver new services that improve the quality of life of individuals and communities using innovative processes aiming for instance at new labour market integration, social inclusion, finding new ways to address health care, education delivery, resource efficiency and environmental challenges". (European Commission, 2011).

“Social innovation' seeks new answers to social problems by: identifying and delivering new services that improve the quality of life of individuals and communities; identifying and implementing new labour market integration processes, new competencies, new jobs, and new forms of participation, as diverse elements that each contribute to improving the position of individuals in the workforce." (OECD Forum on Social Innovation, 2000).

- In the same way, many works are devoted to social innovation in particular service activities, without any real link being made with the field of the socio-economics of innovation in services. These service activities include home help services (Degrave and Nyssens, 2008), public services in general (Barreau, 2002), etc.

- A few rare (and recent) works, lastly, confine themselves to briefly highlighting (without going into detail) the need to add innovation in services issues to the research agenda on social innovation. This is the case for Howaldt and Schwarz (2010) and Mulgan et al. (2007). Mulgan et al. (2007, p. 43) note that: "another major issue is that most understanding of innovation has been derived from studying manufacturing. Less is known about innovation in services - and many businesses involved in services find the innovation literature unsatisfactory (IBM for example has called for a new 'services science' to rectify this). Ian Miles' work at Manchester is a rare exception of work that is both theoretically sophisticated and grounded in empirical observation and data."

\subsection{Putting social innovation and service innovation into perspective}

We will address a number of points (similarities, differences, etc.) in this section that merit debate or should form the subject of a more in-depth debate between social innovation and service innovation.

Social innovation: innovation in services and service innovation 
The links between social innovation and services can be considered from two different angles: one sectoral (social innovation as innovation in services) and the other functional (social innovation as service innovation).

A specific characteristic of social innovation is that it can develop in any socio-economic field and any sector: inside and outside firms, in the public, semi-public and private sectors, in services, in the industrial and agricultural sectors, in civil society, etc. It is often a service innovation, even when it does not emerge in the services sector. In fact, whatever the sector in question (including industry and agriculture), social innovation often consists of supplying "services" to address socio-economic problems. While this observation can be applied to the contemporary economy, it also holds true for historical analyses. An overview of the history of social innovations (generated by or concerning industrial workers) in the capitalist economies of the $19^{\text {th }}$ century mainly brings to light service innovations. One example (Harrisson et al., 2010) is the setting up of various types of cooperatives and the implementation of various worker protection services (funeral management, social funding to acquire accommodation, etc.).

However, although it transcends economic sectors, tertiary and service activities are a particularly fertile environment for social innovation. While it concerns all services, it has enjoyed particularly strong growth in the following sectors: the public sector, personal services and in particular the sector of social and solidarity economy or "third sector" (consisting of not-for-profit organisations and of cooperatives or mutual insurance companies that support business development).

This key relationship between social innovation and service sectors can be explained in a number of ways. The first explanation is a mechanical one: the growing share of services in today's economies, both in terms of wealth creation and job creation. However, this link can be explained primarily by the particular nature of service activities, which are based on intensive social interactions between consumers, users and producers. It can also be explained by the nature of the values (fairness and solidarity) prevailing in the public and third sectors (social and solidarity economy).

\section{Theoretical perspectives}

The field of innovation in services, like that of social innovation, seeks for theoretical frameworks capable of taking into account their nature and dynamics. The obvious point of reference for both fields is industrial innovation and it is therefore not surprising that they have attempted to develop and define themselves in relation to the solid academic field of industrial innovation. However, despite this common anchoring point, these theoretical perspectives have followed different paths to arrive at the same result: taking into account both the technological and non-technological dimensions.

In fact, as we mentioned in the first section, in the services field, the issue of innovation has moved through a number of stages, from a lack of recognition to an assimilation to technological (or more generally industrial) innovation, then to demarcation and finally integration or synthesis. The assimilationist perspective (according to which innovation in services is similar to innovation in industry) has long been the dominant approach and it continues to be influential today.

It is the demarcation perspective, on the other hand, which immediately dominated the social innovation field, defined as it is in opposition to industrial innovation (technological innovation). The assimilationist perspective (or at least partially assimilationist), which takes 
into account certain forms of technological innovation in social innovation (such as green technologies), is a fairly late development. The extreme, universalist perspective of social innovation should not be confused with the integration perspective favoured in services. In fact, it does not include different types of innovations in a single model, but it only considers innovation and social innovation as synonyms.

Overall, to a certain extent, by drawing on industrial innovation in different ways, the schools of social innovation and service innovation have followed the same path between assimilation and demarcation, but in reverse. After taking different directions, they have arrived at a similar perspective in which, ultimately, social innovation, like service innovation, is considered from both the point of view of its technological components (assimilation) and its non-technological components (demarcation).

\section{The nature and measurement of innovation}

Intangibility is an obvious point in common long debated by both the social innovation and service innovation literature. This commonality underlines how certain service innovations are social innovations. However, it is not, of course, sufficient to systematically establish an identity between service innovation and social innovation. In fact, as seen in section two, certain "intangible" results of social innovation are not products/services but rules, behaviours, laws and institutions. In addition, innovation in services, just like social innovation, is not necessarily intangible, since it can in both cases be embodied in a technical artefact.

Like service innovation, social innovation is difficult to grasp in a survey. Since they exist in a wide variety of forms, including products, services, processes, organisations, principles, laws and institutions, and especially a combination of all or part of these elements, they are difficult to measure. A sustainable tourism package or fair trade, for example, is difficult to fit into the official categories of questionnaires. They are combinatorial by nature and newness is often the result of a combination of already existing elements. Sustainable tourism combines elements such as hotels, restaurants, transport, booking arrangements, natural landscapes, etc. Similarly, "diagnostic health lines" associate a telephone, a nurse and a diagnostic software. The problem, in the case of social innovations, also relates to the institutional unit that takes responsibility for them. It no longer concerns just the firm. It also involves analytical categories - citizens or heterogeneous groups containing a large number and variety of stakeholders - which are difficult to adapt to surveys.

However, although international institutions have made considerable efforts to develop indicators to facilitate the measurement of innovation in services (Oslo Manual, OECD), this is not the case for social innovation. It is possible that certain social innovations in business (technical artefacts that have a social component and certain organisational innovations relating to improvements in working conditions or rearrangements of power structures) are now taken into account (at least partially) without being considered from the point of view of their social innovations facet. The positive externality effect generated by advances in taking service innovations into account is not, of course, sufficient in itself. A greater effort needs to be made to positively measure social innovation in itself.

\section{The issue of appropriation}

Within the framework of service innovation, the issue of appropriation regimes is considered from the positive angle of the difficulty of protecting intangible and interactive outputs. The discussion therefore focus not on the legitimacy of protection, but on the technical methods of 
appropriating innovations which do not fall within the scope of conventional technical methods, such as patents (Miles et al., 2000; Blind et al., 2010). Within the social innovation framework, the issue of protection is rarely raised or not considered as a legitimate issue. A social innovation is a success when it goes beyond its promoters, in other words, when it is imitated by others. This applies to microcredit, for example, and the famous Grameen Bank created by Muhammad Yunus and which won the Nobel Peace Prize, or the Restos du cœur food service for the homeless. This conclusion should be put into context, of course, because it is more difficult to apply when considering material artefacts. In addition, appropriation can be a source of conflict when social innovation is delivered by hybrid networks containing stakeholders from varying backgrounds (public, private and civil society). In fact, appropriation regime approaches differ between public and non-profit organisations and private organisations. The first are working in the public interest and distribute knowledge to a wide audience. The second are concerned with private appropriation of value added sources.

\section{Organisational modes for innovation}

The participation of the customer and the user (coproduction) plays a central role in both service innovation and social innovation. In the case of social innovation, certain authors do not hesitate to define the essential nature of social innovation in relation to coproduction, in other words, to identify the nature of innovation with its mode of organisation. The linear innovation model is conceivable in both fields of research. In both cases, material artefacts can be developed in a laboratory system according to a linear procedure. In the same way, the implementation of certain new services (particularly financial or insurance services) can fall within the scope of the linear and "stage-gate" approach of the "New Service Development" (NSD) models. However, in social innovation, as in service innovation, what dominates is openness and interaction, along with informal and unplanned activities. The partnerships, which we have called Public-private innovation networks in services (servPPINs) (Gallouj, Rubalcaba, Windrum, 2012), are new institutional arrangements that take into account the way in which different stakeholders interact to produce not only technological innovations but also social and service innovations.

\section{Performance measurement issues}

To assess the performance of service organisations, the services economics has developed a multi-criteria assessment tradition that can be applied to social innovation, whether it relates to services or otherwise (Gadrey, 2006; Djellal and Gallouj, 2008). Drawing freely on the work of the School of Conventions (Boltanski and Thévenot, 1991), it is assumed that the effects of social innovation can be defined and evaluated according to different justificatory criteria corresponding to the five following types of performance: industrial and technical performance (focusing on volume and traffic evaluations), market and financial performance (focusing on monetary and financial operations), relational performance (relating to interpersonal links), civic performance (relating to equality, fairness and justice), and reputational performance (relating to brand image). Contrary to certain preconceptions, civic, relational and reputational performance are not closed to all forms of quantification.

\section{Conclusion}

Social innovation and service innovation are two still marginal but particularly dynamic fields of research that are in what Kuhn describes as a pre-paradigmatic phase, that is, a period in which a multitude of definitions and more or less contradictory theories compete with each other without one imposing itself on the others. These fields have both been developed (in positive and negative ways) based on the well-established academic fortress of industrial and 
technological innovation. Despite numerous analytical affinities (and even sometimes the same identity), and similar theoretical and methodological problems, these two fields have developed in parallel, only intersecting on rare occasions.

This article has endeavoured to establish a certain dialogue between these two fields of research, with mutually rewarding results for both. The fact that social innovation is often a service innovation but also just as often (and increasingly) an innovation in services makes this dialogue all the more desirable. In fact, the services sector is a particularly fertile ground for social innovation. This is true of market services, taking into account the density of social interactions (particularly with customers) that characterise them. It is even more true of public administrations, in which the density of these social interactions is formed in a "public service spirit" based on the principles of fairness, equality of treatment and continuity. This is also true to an even greater degree for the rapidly expanding conglomeration of tertiary activities in developed economies, which are grouped under the term "third sector" (social and solidarity economy).

The areas for dialogue raised in this exploratory paper are the theoretical perspectives favoured, the nature of innovation and the question of its identification and measurement, its modes of organisation, its appropriation regimes and the evaluation of its impacts. However, other areas would also merit attention, in particular public policies to support social innovation and service innovation. A better understanding of social innovation in the light of service innovation and vice versa is likely to help reduce even further the hidden or invisible innovation gap in our economies and enable us to advance towards a new comprehensive innovation paradigm.

\section{Bibliography}

Barreau J. (2002), Les services publics français et l'innovation sociale in Djellal F. et Gallouj F., (eds), p. 165-185.

Becheikh N., Halilem N., Jbilou J., Landry R. (2009), Vers une conceptualization de l'innovation dans le secteur public, Economies et Sociétés, Série EGS, n¹0, 4/2009, p. 579-614.

Blind K., Evangelista R., Howells J. (2010), Knowledge Regimes and Intellectual Property Protection in Services: A Conceptual Model and Empirical Testing, in Gallouj F., Djellal F. (eds), The Handbook of Innovation and Services, Edward Elgar.

Boltanski, L. et Thévenot, L. (1991), De la justification. Les économies de la grandeur, Gallimard, Paris.

Callon M., 1991, Réseaux technico-économiques et irréversibilité, in Boyer., et al. (ed.), Figures de l'irréversibilité en économie, Paris, Edition de l'EHESS, p.195-230.

Chambon, J.-L., David A. et Devevey J.-M. (1982), Les innovations sociales, Paris : Presses Universitaires de France.,Collection Que sais-je.

Cloutier J. (2003), Qu'est-ce que l'innovation sociale?, Cahier de recherche du CRISES, ${ }^{\circ}$ ET0314, UQAM, novembre.

Crozier M., Normann R., Tardy G. (1982), L'innovation dans les services, Mission à l'innovation, rapport $\mathrm{n}^{\circ} 8$, mars.

Dandurand L. (2005), Réflexion autour du concept d'innovation sociale, approche historique et comparative, Revue française d'administration publique, $3, \mathrm{n}^{\circ} 115$, p. 377-382.

De Brentani U. (1991), Success factors in developing new business services, European Journal of marketing, 25(2), p. 33-59. 
Degrave F., Nyssens M. (2008), L'innovation sociale dans les services d'aide à domicile. Les apports d'une lecture polanyienne et féministe, Revue française de socio-économie, 2008/2, p. 79-98.

Den Hertog P. (2002), Co-producers of Innovation: On the Role of Knowledge-Intensive Business Services in Innovation, in Gadrey, J. and F. Gallouj (eds) Productivity, Innovation and Knowledge in Services, Cheltenham: UK, Edward Elgar, pp.

Djellal F. (1995), Changement technique et conseil en technologie de l'information, L'Harmattan.

Djellal F., Gallouj F. (2008), Measuring an Improving productivity in services : issues, strategies and challenges, Edward Elgar Publishers, Cheltenham.

Djellal F., Gallouj F. (2010), Innovation in services and sustainable development, in Kieliszewski, Maglio et Spohrer (eds), The Handbook of Service Science, Springer, 533557.

Drewe, P., Klein, J.L. and E. Hulsbergen (eds) (2008), The Challenge of Social Innovation in Urban Revitalization, Amsterdam: Techne Press.

Edquist C. (ed) (1997), Systems of Innovation : technologies, Institutions and Organizations, Pinter.

European Commission (2011), FP7 Cooperation Work programme 2011, theme 8, Socioeconomic sciences and humanities.

Freeman C. (1991), Innovation, change of technoeconomic paradigm and biologico analogies in economics, Revue économique, $\mathrm{n}^{\circ} 2$, mars, p. 211-232.

Fuglsang L. (2010), Bricolage and invisible innovation in public service innovation, Journal of Innovation Economics, 1(5), p. 67-87.

Furrer O. (2010), A customer relationship typology of product services strategies, in Gallouj F., Djellal F. (eds), The handbook of innovation and services, Edward Elgar.

Gadrey J. (1996), Services : la productivité en question, Desclée de Brouwer, Paris.

Gadrey J. and F. Gallouj (1998), The provider-customer interface in business and professional services, The Service Industries Journal, 18 (2), April, 1-15.

Gadrey J., Ghillebaert E., Gallouj F. (1999), Formes et coûts de la production de cohésion sociale dans les relations de service public : le cas des guichets à La Poste, Liens social et politiques-Revue internationale d'action communautaire, 40, automne, p. 75-87

Gallouj F. (1991), Les formes de l'innovation dans les services de conseil, Revue d'économie industrielle, $\mathrm{n}^{\circ} 57$, troisième trimestre, p. 25-45.

Gallouj F. (1994), Economie de l'innovation dans les services, Editions L'Harmattan, Logiques économiques, Paris.

Gallouj F. (2002a), Innovation in services and the attendant old and new myths, Journal of socio-economics, Vol. 31, p. 137-154. 31, p. 137-154.

Gallouj F. (2002b), Innovation in the service economy: the new wealth of nations, Edward Elgar Publishing, Cheltenham.

Gallouj F. (2010), Services innovation: assimilation, differentiation, inversion and integration, chapter 75, in Bidgoli H. (ed), The Handbook of Technology Management, John Wiley and Sons, p. 989-1000.

Gallouj F. et Weinstein O. (1997), Innovation in Services, Research Policy, Vol. 26, n4-5, p. 537-556.

Gallouj F., Djellal F. (eds) (2010), The Handbook of Innovation and Services: a multidisciplinary perspective, Edward Elgar Publishers.

Gallouj F., Rubalcaba L. Windrum P. (2012), Public Private Innovation Networks in Services, Edward Elgar (forthcoming). 
Gallouj F., Savona M. (2009), Innovation in services: a review of the debate and perspectives for a research agenda, The Journal of Evolutionary Economics, Volume 19, 2, p. 149-172.

Gershuny J. (1978), After industrial society? the emerging self-service economy, Mac Millan. Gershuny J. (1983), Social innovation and the division of labour, Oxford University Press.

Gershuny J. Miles I. (1983), The new service economy : the transformation of employment in industrial societies, Frances Pinter.

Goldenberg M. (2004), L'innovation sociale au Canada. Comment le secteur à but non lucratif sert les Canadiens, Rapport de recherche W/25, Réseau de la main-d'œuvre, Réseaux canadiens de recherche et politiques publiques, Ottawa. www.rcrpp.org.

Hamalainen, T.J., Heiskala, R. (Eds), Social Innovations, Institutional Change and Economic Performance, Edward Elgar, Cheltenham, p. 52-79.

Harrisson D. and Klein J.L. (2007), Introduction : Placer la société au centre de l'analyse des innovations in Juan-Luis Klein and Denis Harrisson (eds), L'innovation sociale: Émergence et effets sur la transformation des sociétés, Québec: PUQ, p. 1-14.

Harrisson D. and Vézina M., (2006), 'L'innovation sociale : une introduction', Annals of Public and Cooperative Economics, 77 (2), 129-138.

Harrisson D., Klein J.-L., Leduc Browne P. (2010), Social innovation, social enterprise and services, in Gallouj F., Djellal F. eds, The Handbook of Innovation and Services: a Multi-disciplinary Perspective, Edward Elgar, p. 197-218.

Hillier J., Moulaert F., Nussbaumer J. (2004), Trois essais sur le role de l'innovation sociale dans le développement territorial, Géographie, Economie et Société, 2004/2, Vol 6, p. 129152.

Hipp, C. and H. Grupp (2005), Innovation in the service sector: the demand for servicespecific innovation measurement concepts and typologies, Research Policy, 34 (4), 517535.

Hochgerner J. (2009), Innovation process in the dynamics of social change, in Loudin J., Schuch K. (eds), Innovation cultures. Challenge and Learning Strategy, Prague, Filosofia, p. 17-45.

Howaldt J., Schwarz M. (2010), Social Innovation: Concepts, research fields and international trends, Sozialforschungsstelle Dortmund ZWE der TU-Dortmund.

Howells J. (2007), Services and innovation: conceptual and theoretical perspectives, in Bryson, J. R. and P. W. Daniels (eds), The Handbook of Service Industries, Cheltenham: Edward Elgar, pp.

Kline S., Rosenberg N. (1986), An overview of innovation in Landau R., Rosenberg N. (eds), The positive sum strategy: harnessing technology for economic growth, National Academy Press, Washington DC.

Kubr M. (1988), Management Consulting : a Guide to the Profession, BIT, Genève.

Kuznets S. (1974), Population, capital and growth : selected essays, Heinemann Educational, London.

Lallemand D. (2001), Les défis de l'innovation sociale, Issy-les-Moulineaux, ESF Editeur.

Laville J.-L. (2010), sociologie des services, èrès.

Lévesque B. (2005), Innovations et transformations sociales dans le développement économique et le développement social : approches théoriques et politiques publiques, mai, Cahiers du CRISES n ${ }^{\circ}$ ET0507, UQAM.

Lundvall B.-A. (ed) (1992) National systems of innovation, Pinter Publishers.

Miles I., Kastrinos N., Flanagan K., Bilderbek R., den Hertog P., Huntink W., Bouman M. (1994), Knowledge-Intensive Business Services: Their Role as Users, Carriers and Sources of Innovation, PREST, University of Manchester. 
Miles I. (2002), Services innovation: Towards a tertiarization of innovation studies, in Gadrey J. and F. Gallouj (eds), Productivity, Innovation and Knowledge in Services, Cheltenham UK, Northampton USA: Edward Elgar, pp.

Miles I., Andersen B., Boden M., Howells J. (2000) Service Production and Intellectual Property. International Journal of Technology Management, 20(1/2): 95-115.

Moulaert F., Martinelli F., Swyngedouw E. and Gonzalez S. (2005), Toward Alternative Model(s) of Local Innovation, Urban Studies, 42 (11), 1969-1990.

Mulgan G., Tucker S., Rushanara A., Sanders B. (2007), Social innovation: what it is, why it matters and how it can be accelerated, Skoll centre for social entrepreneurship, Oxford Said Business school, working paper, The Young Foundation.

Normann R. (1984), Service management: strategy and leadership in service business, John Wiley and sons.

OECD (2005), "Proposed guidelines for collecting and interpreting technological innovation data", Oslo manual. OECD, Paris.

OECD LEED Forum on Social Innovations (2000) http://www.oecdorg/document/53/0,3343, fr 264934459392632211111 ,00.html-28k-.

Perez C. (1983), Structural change and the assimilation of new technologies in the economic and social system, Futures, vol. 15, n 4 , p. 357-375.

Phills J.A., Deiglmeier K., Miller D.T. (2008), Rediscovering social innovation, Stanford Social Innovation Review, Fall, p. 34-43.

Pole E., Ville S. (2009), Social innovation : Buzz word or enduring term ?, The Journal of Socio-Economics, 38, p. 878-885.

Rubalcaba L. (2006), Which policy for innovation in services? Science and Public Policy, 33 (10), 745-756.

Sanger M. B., Levin M. A. (1992), Using Old Stuff in New Ways: Innovation as a Case of Evolutionary Tinkering, Journal of Policy Analysis and Management, 11(1), p. 88-115.

Scheuing E.E, Johnson E.M. (1989), A poposed model for new service development, Journal of service marketing, 3(2), p. 25-35.

Schumpeter J. (1975)[1942], Capitalism, Socialism and Democracy, Harper, New York.

Styhre A. (2009), Tinkering with material resources: Operating under ambiguous conditions in rock construction work. The Learning Organization 16 (5), p. 386-397.

Sundbo J, Gallouj F. (1999), Innovation as a loosely coupled system in services, International Journal of Services Technology and Management, Vol. 1, $\mathrm{n}^{\circ} 1,15-36.1, \mathrm{n}^{\circ} 1,15-36$.

Sundbo J. (1998), The organisation of innovation in services, Copenhagen: Roskilde University Press.

Tether B., (2005), Do Services Innovate (Differently)?: Insights from the European Innobarometer Survey, Industry and Innovation, 12, 153-184.

Tidd J., Hull F. (2010), Service innovation: development, delivery and performance, in Gallouj F. Djellal F. (eds), The handbook of innovation and services, Edward Elgar, p. 250-278.

Toivonen M. (2010), Different types of innovation processes in services and their organisational implications, in Gallouj F. Djellal F. (eds), The handbook of innovation and services, Edward Elgar, p. 221-249.

Windrum P., Koch P. (ed.) (2007), Innovation in Public Sector Services - Entrepreneurship, Creativity and Management, Cheltenham UK, Northhampton MA, USA, Edward Elgar.

Windrum P., Garçia-Goni M. (2008), A neo-Schumpeterian model of health services innovation, Research Policy, 37 (4), 649-672. 